\title{
Lebanese Newspapers Framing of Syrian Refugees: A Content Analysis
}

\author{
Liliane Karam \\ Lecturer \\ George N. Farha \\ Associate Professor \\ Department of Communication Arts \\ American University of Science \& Technology \\ Alfred Naccash Avenue \\ Lebanon
}

\begin{abstract}
The media has always played a conventional role in shaping public perceptions on critical social events. Syrian refugees have escaped to Lebanon in enormous numbers since the start of the war in their country in 2011. Evacuees are evaluated at anywhere in the range of 1.3 to 1.5 million, with unregistered numbers moving toward 2 million, in comparison with Lebanese population assessed at 4.5 million. At the onset of the emergency, pressure grows, policies develop, and relationships between refugees and host communities become unsteady. The purpose of this study is to showcase how Syrian displaced refugee stories overwhelm Lebanese daily newspapers. By using the framing theory as a mechanism, this study scrutinizes the prejudice content manifestation of socio-cultural, economic, security, and humanitarian related news with a subsequent attempt at investigating how news media help shaping the attitudes and perceptions of the Lebanese public towards the Syrian crisis. A quantitative content analysis is used to analyze a sample of news articles from four national newspapers. Results show that prejudice coverage fosters socio-cultural, economic, and security threat perceptions among the Lebanese public, despite the positivity in covering humanitarian refugees' stories.
\end{abstract}

Keywords: Lebanon, Syrians, migrants, refugees, framing, Lebanese newspapers, prejudice, socio-cultural, economic, safety, humanitarian.

\section{Introduction}

It is broadly recognized and accepted that the nature of the messages imparted by the media in all their structures can clearly affect general societal states of mind, which can of course have an orientation on conduct (Bryant \& Oliver, 2009). This is truly important when it comes to covering stories and news related to migration leading in turn to shaping people's attitudes and perceptions about surroundings. Despite its historical element of human presence, migration has been frequently deliberated as a recent phenomenon, although people have considerably migrated in gatherings and as individuals to escape from war, famine, poverty, religious or political bigotry, trade or even to discover new places. Media and migration have been the interest of many scholars around the world, as they have tried to understand the effects of the media coverage on the way refugees and migrants have been living, surviving and creating new type of communities in the hosting countries. Numerous literature worldwide have verified the role of media as a platform to frame an image about migrants and minority groups(Brewer \& Gross, 2005; Chong \& Druckman, 2007a and b).Consequently, Zaller (1992:311) hypothesized that the framing of the rival messages that recur most frequently in the media will influence the most on the formation of people's opinions. However, such hypothesis predicts that the recipients of these competing messages will passively evaluate how these messages are framed and simply hold them as they often hear them (Cappella and Jamieson, 1997: 81-82; Nabi, 2003: 225).Alternatively, Brewer (2001) assumed that whether repeated or not, the "strongest frame" will have a significant impact on opinions. The key here depends on the quality and credibility of the framing source of the messages with regard to their relationship to common values (Druckman, 2001b).

Accordingly, further research investigated the psychological effects of message framing. Lippman (1922) studied people's attitudes about World War I and penciled a whole chapter "The World Outside and the -Pictures in Our Heads." He explained how the psychology of public opinion was influenced by the news media as a crucial foundation of pictures in people's heads about the larger world of public affairs. Bless, Fiedler, and Strack (2004) studied psychological processes to assess people's opinions on a given situation. 
They first assumed that people must store the particular situation in their brain for them to be able to retrieve it later (e.g., Eagly and Chaikin 1993: 131, 329), which means that only the people who are interested in a particular situation will be affected by the framing.

However, the prolonged emphasis on the situation will increase its accessibility and therefore improve people's interest in it (Higgins 1996; Sherman, Mackie, and Driscoll 1990; also see Iyengar 1991; Zaller 1992 on accessibility and framing). Thus, the repetition of the framing of a particular message in a specific situation might lead to an increase in its accessibility and eventually enhances the people's interest in it (Bargh, Lombardi, and Higgins 1988; Bless, Fiedler, and Strack 2004: 48). Moreover, accessibility of framing alone may not impact on people's opinions (Althaus and Kim, 2006; Nelson, Oxley, and Clawson, 1997; Price and Tewksbury, 1997). This impact occurs only in the situations when people consciously evaluate accessible concerns driven by sufficient motivation (Fazio, 1995; Stapel, Koomen, and Zeelenberg, 1998). Notwithstanding, migrants all over the world have been portrayed negatively in news media. They have been "dehumanized" and have disseminated the idea of social crisis (Blinder, 2015).

According to the United Nations Department of Economic and Social Affairs (2013), the number of global migrants has increased from 77 million in 1960 to around 234 in 2013. With the expanding rate of universal people movement, there are clear ramifications for policy-makers originating from how movement is depicted in the media. The exposure to representations of migrants and refugees in the media has driven to a vulnerable echoing towards this movement (Hugo,Aghazarm \& Appave, 2011). Moreover, the Essentials of Migration Management (2014) argued that the dialect used in the discourse of migration and refugees movement stemmed from government officials, media and scholastics, creating a framework to the impressions about the stories. Therefore, the stories that the media deliver formulate the way people perceive them.

Nonetheless, political and military situations in the $20^{\text {th }}$ and 21 st century gave birth to more and more migration and refugee crises. According to the International Organization for Migration (n.d), the biggest migration movement that the world has witnessed as a result of a civil war in the past decade, is the Syrian migration estimating the evacuation of more than 11 million persons since March 2011.Among those getting away from the conflict, the larger part have sought refuge in neighboring nations or inside Syria itself. As per the United Nations High Commissioner for Refugees (UNHCR), 4.8 million have escaped to Turkey, Lebanon, Jordan, Egypt and Iraq, and 6.6 million have displaced inside Syria. In the meantime, around one million have asked for refuge to Europe. Germany, with more than 300,000 cumulated applications, and Sweden with 100,000, are EU's top accepting nations (IOM, n.d.).

Besides, the Lebanese government has historically kept up an open entryway strategy towards Syrian exiles; in any case, the UNHCR stated that the Lebanese government has never ratified the 1951 Refugee Convention which secures a neighboring country refugee by virtue of any reason. Therefore, there exists no international laws which Lebanon must follow in managing the refugee crisis, which has incorporated the administration of Lebanon into not assembling organized refugee camps. As a consequence, the refugees who are equipped for work must compete with the poor of Lebanon for the country's most reduced paying employments to get work and profit. This has brought about harm to Lebanon's monetary framework according to many critics. The Syrian children must go to the same schools with Lebanese youngsters, and as the numbers of Syrians in Lebanon have grown, so have social tensions (Crossman, n.d.).

The purpose of this study is to showcase how, at the onset of the emergency, the Syrian displaced refugee stories have been covered and depicted by the Lebanese media in general and the daily newspapers in particular. The study examines the prejudice content manifestation of socio-cultural, economic, security, and humanitarian related news with a subsequent attempt at investigating how news media helped shape the attitudes and perceptions of the Lebanese public towards the Syrian crisis. This study applies the framing theory developed by Bateson (1972) as a basis to which the media design the news (positively or negatively) and deliver them to the public. It explains how the selection of certain events concerning the Syrian refugees within a specific framework lead to conflicting interpretations by the Lebanese recipients and create an impact on their attitudes and perception towards them. The framework displays the content of news concerning socio-cultural, economic, security, and humanitarian stories chosen by reporters who in turn decide on how they will report them to reinforce a certain negative discriminatory belief about the potential threats on Lebanese citizen's jobs, society, and safety among others.

\section{Literature Review}

Unfavorable attitudes toward immigrants of diverse races and ethnicities have been examined in many studies through applying different research methods (Fetzer, 2000; Brader et al). Messina (2007) pointed to the prevalent confrontation of immigrants from national publics. Citrin and Sides (2008) studied the opinions of both American and European public and discovered that both populace opposed the increase in the number of immigrants in their countries. Ceobanu and Escandell (2010) displayed a comparative multinational data against immigrants. 
Blinder (2015) linked public opinion toward immigrants and immigration to pictures in British people heads of immigrants rather than immigration, despite the fact that the sources of information about immigration - whether direct experiences, social interactions or media sources - didn't provide complete depictions of a large- scale social phenomenon.

However, he contended that this "imagined immigration" is strongly related to individual preferences for reduced migration. Moreover, studies allocated different causes for individuals' opinions towards immigrants. Some studies revealed that economic factors reflecting competition of immigrants on the nation's labor force are main causes for opposition (Facchini et al., 2013; Hainmueller and Hiscox, 2010; O'Rourke and Sinnott, 2006). Some others linked it to cultural ingredients and ways of lives (Sniderman et al., 2004). Many others detected threat perceptions in their findings (Quillian, 1995; Semyonov et al., 2008).

Moreover, Figenschou, Beyer and Thorbjornsrud (2015) argued that news stories have often portrayed blacks as "intruders or threats" shaping national perceptions about them. Their study stressed on assessing the costs and benefits generated by the presence of migrants and refugees in western nations stating the obligations that the nations have towards them. These obligations have led to an ambiguity and fear among policy makers and constituents. They have questioned the extent to which they pose competitive and financial burden on the hosting nations' own people. Besides, the study proposed that the media will probably benefit from such ambiguity to feed their news with spicy materials that transform everyday ordinary materials to "scoops," fueling the public attitudes and perceptions about migrants or refugees.

Threadgold (2009) argued that parlance regarding refugee movements stems from government officials, research evidence and media representatives which in turn "set the motivation and frame the stories" to further encourage changes in the cycle of policy making. A recent study conducted by the Australian government focused on the representations of refugees in the media and the effects of media coverage on how people behave towards such crisis. The study revealed that most sampled media concentrated more on framing humanitarian and financial threats. However, reporting in social and security settings was predominant in connection to irregular relocation and individuals "carrying and trafficking" (McAuliffe, 2016).

Consequently, France Strategy Activity Report (2016) pointed to the challenges that face the European Union in coping with migration. Concerns were again being expressed in some circles over what was seen as unfair competition from immigrants in the labor market and their potential negative impact on public finances. Supervising these potential sources of social tension and labor threats presented a serious challenge to governments of developed countries.

Irving (1990) emphasized on the role of media in promoting sociocultural pressures on people. As a result, the negative framing of Syrian refugees has led to a pervasive social strain among the Lebanese citizens. Subsequently, Bryant \& Oliver (2009) emphasized on the repetitive theme of the world echoed to form a particular social mandate. Nonetheless, the arguments about relocation introduced in particular fragments of the media help contextualizing the attitudinal and behavioral patterns as they unfold with expanding worldwide movement. This point is especially notable in what (Castles, De Haas, \& Miller, 2014) have portrayed as the 'time of migration', including a continuously expanding number of individuals moving globally for a scope of reasons including work, assurance, family get-together among others. Thus, it is likely that the media motivation impacts policymaking in destination nations, especially because of a feeling of "emergency" connected to migration.

\subsection{Syrian Refugees and Media Coverage in Lebanon}

The classic prejudice constructed initially with respect to the biological distinction between races (de Gobineau, 1855). However, the birth of neo-prejudice depended on nationalism and signaled the hatred towards foreigners considering them negative characters that threaten a nation's security (Maharat, 2016). Notwithstanding, Forbes-Statist/UNHCR (2014) reported an estimated 257 refugees per 1,000 tenants in Lebanon. Lebanon's population is assessed at 4.5 million, yet, Syrian evacuees are evaluated at anywhere in the range of 1.3 to 1.5 million, with unregistered numbers mounting to 2 million. Pressure grows, policies develop, and relationships between refugees and host communities began to change. There were signs that Syrian refugees have become increasingly vulnerable, while worries were rising among Lebanese host communities. One main reason to such an escalated number was that Lebanon did not gather to the Geneva Convention of 1951 to identify with the refugees status. Thus, the Lebanese government has been attempting to go up against the emergency leaving it unsupervised (Alsharabati, 2014) which made the refugees, fueled by media negative framing, seen by some Lebanese as a serious threat to the country's economy, social coherence and infrastructure. Regardless of that, Lebanon proceeded with its approach of "open borders" (McAuliffe, 2016). 
Adding to the complexity of the situation, some Syrian refugees have been engaged in crimes and kidnappings, which further fueled pinning refugees to security concerns. Although the refugee situation continued to be primarily of a humanitarian nature, recent developments have led all players concerned to view refugees through a "security prism" (Maharat, 2016). Furthermore, the level of aid received by them and the unsupervised distribution of the aids received to the host communities, impacted on employment since employers preferred low-priced Syrian labors over Lebanese counterparts(Sqour, Rjoub, andTarrad, 2014).

The aforementioned factorshave fueled the discourse of almost all the newspapers, electronic media outlets, and TV and Radio stations in Lebanon using prejudice and judgmental language in their coverage diffusing hatred talk, and playing the cards of identity, entity, socioeconomics, subsistence and national security.

Hence, an alarming article titled, "Before Lebanon Turns into a Depot for War Refugees" in the everyday Al Joumhouriya on July 12, 2015, highlighted on the emergency taking note that no nation has needed to face outcast numbers that nearly coordinated its populace (Abu-Fadil, 2015).Accordingly, Maharat Foundation (2016) revealed that negative tone towards Syrian refugees primarily identified with the security news, including assaults and safety efforts, and with work constraints and economic burden that threatened the country's stability. The frequently used terms in media coverage included "ticking time bomb," "fear," "security," "burden,"..."threatens," and "threatens the Lebanese model." The vocabulary utilized as a part of some of the coverages played on the memory of the Lebanese common war time frame to increase the fear from the outcasts.

Nonetheless, Al Joumhouriya newspaper's off-base inquiries in features and online substance have often questioned who ensures Lebanese rights to occupations? What do Lebanese workers say with regards to unlawful rivalry? After security, how does Syrian relocation influence the Lebanese economy? What's the Labor Ministry doing?" The newspaper also reported that "every gathering by Syrians is a sleeper cell [directed] against the security, economic, livelihood, or environmental [sectors]."

\subsection{The Framing Theory: The Theoretical Framework of the Study}

The heart of framing theory as developed by Bateson (1972) is that the media focus attention on certain events and then place them within a field of meaning. In essence, framing theory suggests that how something is presented to the audience (called "the frame") influences the choices people make about how to process that information (Cacciatore, Scheufele, \& Iyengar, 2016). The media tend to frame the events that are most proximate at the time of reporting. Journalists are the ones who select subjectively which events to cover and how to cover them based on social norms, interest group pressure, political orientations and daily occurrences. Frames are cultural in nature reflecting social norms and virtues passed on to people. They are thought to influence the perception of the news by the audience, in this way it could be construed as a form of second level agenda-setting in a sense that they don't only tell the audience what to think about, but also how to think about that issue (Mass Communication Theory, n.d.).

Thus, when confronted with news, people perceive them through their own frames, make new materials out of them, choose what they identify with and ignore what is not appropriate for them. So, when journalists decide to present a new frame to the public, they reinforce concepts that are accepted culturally. Furthermore, according to Chong \& Druckman (2007a), people may sometimes passively perceive some of the frames they encounter. However, they will most probably critically assess the applicability and the relevance of the frames they are interested in and that impact on their opinions. Such applicability is mostly influenced by the logic behind the framing and the credibility of the source. For example when framing Syrian refugees in any of the highly ranked newspapers in Lebanon as beggars, terrorists, burdens, thieves or rapists, journalists may intend to motivate people to try to solve a pressing socio-cultural problem away from their political leaders.

\section{Research Questions}

Goffman (1974) related people's interpretation of the events they encounter regularly to what he referred to as "primary framework." However, he classified primary framework as both natural and social to influence the way people interpret, process, and communicate information in social contexts. Precisely, based on framing theory, this study examines the content of socio-cultural, economic, humanitarian, and security news covered by leading Lebanese newspapers in order to understand how such prejudice coverage can make Lebanese people perceive Syrian refugees as a threat to their society.

Q1. Which concepts were mainly framed by news media when reporting socio-cultural, economic, humanitarian, and security events?

Q2. Which prejudice terms were used to report socio-cultural, economic, humanitarian, and security events?

Q3. How much coverage of concepts was done to influence people's interpretation, processing, and communicating information in social contexts? 
Q4. What motivational perceptions were intended by such framing?

\section{Methodology}

The methodology adopted in this study consists of a quantitative content analysis aiming at detecting the prejudice discourse of a sample of Lebanese newspapers against Syrian refugees.

Content analysis identifies objectively the content of messages and is considered a valid methodology since it focuses on factual prejudice words utilized rather than on assumptions (Holtsi, 1969). According to the UNHCR (2001), words which offend/hurt/undermine others reflect prejudice. Thus, words like beggar, terrorist, burden, killer, thief, rapist and more were often used to depict Syrian refugees. This methodology is designed based on what Frey, Anderson, and Friedman (1998) identified to be physical, syntactical, propositional, and thematic units of analysis. Thus, the units of analysis are defined, counted, categorized and coded to produce relevant results to the study(Krippendorff, 2004).

Therefore, in light of this research paper, the units of analysis are as follow:

- Physical units: attempt to start the research based on a unit of measurement, which is in this case newspaper articles from An-Nahar, Al Joumhouriya, and AlAkhbar and The Daily Star.

- Syntactical units: Word classes, largely corresponding to traditional parts of speech (e.g. noun, verb, and preposition), are syntactic categories. In this case, they are words used in the written articles that include prejudice syntaxes against Syrians.

- Propositional units: As developed by Dr. Zenon Pylyshyn (1973) and referred to as psychological theory, propositional representations of prejudice emotional and logical statements displayed in newspapers affect the readers' perceptions.

- Thematic units: Common themes related to prejudice, such as security threat, socio-cultural threat, economic threat and humanitarian cases.

\subsection{Sample Size and Procedures}

This study relies on a purposive sampling technique. The researchers have selected only the articles tackling Syrian refugees over a time frame from January 2017 till June 2017. According to the UNHCR, the Syrian refugee crisis was at its peak and received the most coverage during that period.Purposive sampling is a non-probability sampling in which the units under investigation are based on the judgment or discretion of the researcher ((Hejase and Hejase, 2013).

Moreover, the chosen articles were retrieved from AN-Nahar, Al Joumhouriya, Al Akhbar, and the Daily Star, since according to Ipsos Stat survey and "Arab Mass Media," (UNIC, 2013) these four newspapers are of the most read in Lebanon and they represent different political views. Out of 725 daily newspaper issues, in the time frame of 6 months, (January 2017 till June 2017), a total of 204 articles included stories covering Syrian refugee crisis. The articles were distributed among the newspapers as follows: 80 articles in An-Nahar, 58 articles in Al Joumhouriya, 21 articles in Al Akhbar, and 45 articles in The Daily Star.

The collected articles monitored socio-cultural, economic, humanitarian, and security categories. According to the Australian government and the International Organization of Migration,these categories are considered international standards for studies on migrants and refugees. Not only words, but also phrases and statements that have a direct relation to the main prejudice coverage theme were detected, categorized, counted then calculated for each newspaper under the different variables of the study as presented in the tables below.

\section{Results and Findings}

The discrepancy between newspapers regarding the size of coverage shows by analyzing the number of main coverages that each newspaper has dedicated to the Syrian issuesIt appears that majority of the newspapers have dedicated between 4 and 2 articles a week to cover Syrian refugee's stories in Lebanon. Yet the topic seems almost less-existent in Al-Akhbar newspaper, where it received only 21 coverages, which seems low considering the importance of the subject, while it received inflated response in An-Nahar newspaper, since the coverages amounted to 80. Same goes for Al Joumhouriya which granted the subject a major volume of 58 articles. The results of framing showed that out of 204 coverages observed, 78 have tackled the burdens of asylum, and what it entailed in terms of social affairs and the threat of Syrian refugees on the Lebanese society, their behavior, ethics and norms. 58 of them addressed security issues related to Syrians. One can confirm that both subjects regarding attention towards the refugees and the security issues are those that preoccupied the majority of the main coverages. The remaining topics can be listed under these two categories: Economic threat of Syrian refugees, with a total of 40 articles, while articles reporting the humanitarian part of their stories are 28 only. 
The results of framing Socio-Cultural threat (table 1) represented by propositional and syntactical units revealed the most significant coverage. $42.5 \%$ out of An-Nahar articles, $37.91 \%$ out of Al Joumhouriya articles, $23.8 \%$ out of AlAkhbar articles, and $53.33 \%$ out of The Daily Star articles framed news related to society as "Burden, beggar, thief, dirty, filthy, uneducated, dependent, lower class, others." News related to culture were framed as "Syrian as a race, stupid, idiot, naïve, ignorant, masses, mindless, absurd, others." News related to social norms were framed as "selfish, small, unmindful, mean, greedy, inattentive, unreasonable, wanting and others."

Table 1: Content Categories Design of Socio-Cultural Units, Frequency and Percentages

\begin{tabular}{|c|c|c|}
\hline \multicolumn{3}{|c|}{ Socio-Cultural threat representing propositional and syntactical units } \\
\hline ( & \begin{tabular}{|c|}
$\begin{array}{c}\text { Number of articles } \\
\text { that contain } \\
\text { prejudice } \\
\text { words/phrases }\end{array}$ \\
\end{tabular} & \begin{tabular}{|c|}
$\begin{array}{c}\text { Percentage of } \\
\text { Articles that contain } \\
\text { prejudice } \\
\text { words/phrases }\end{array}$ \\
\end{tabular} \\
\hline \multicolumn{3}{|l|}{$\begin{array}{l}\text { Any word or statement that tackle burdens of asylum and represents Syrians as a } \\
\text { threat to: }\end{array}$} \\
\hline \multirow{3}{*}{$\begin{array}{l}\text { Society (Burden, beggar, thief, dirty, filthy, uneducated, dependent, lower class, } \\
\text { others) }\end{array}$} & An-Nahar: 8 & An-Nahar: $10 \%$ \\
\hline & Al Joumhouriya: 6 & $\begin{array}{l}\text { Al Joumhouriya: } \\
10.34 \%\end{array}$ \\
\hline & $\begin{array}{l}\text { Al Akhbar: } 0 \\
\text { The Daily Star: } 3\end{array}$ & $\begin{array}{l}\text { Al Akhbar: } 0 \\
\text { The Daily Star: 6.67\% }\end{array}$ \\
\hline \multirow{3}{*}{$\begin{array}{l}\text { Culture ("Syrian as a race", stupid, idiot, naïve, ignorant, masses, mindless, } \\
\text { absurd, others) }\end{array}$} & An-Nahar: 6 & An-Nahar: $7 . \overline{5 \%}$ \\
\hline & Al Joumhouriya: 4 & Al Joumhouriya: $6.89 \%$ \\
\hline & $\begin{array}{l}\text { Al Akhbar: } 2 \\
\text { The Daily Star: } 4\end{array}$ & $\begin{array}{l}\text { Al Akhbar: } 9.52 \% \\
\text { The Daily Star: } 8.89 \%\end{array}$ \\
\hline \multirow{4}{*}{$\begin{array}{l}\text { Social norms (selfish, small, unmindful, mean, greedy, inattentive, unreasonable, } \\
\text { wanting and others) }\end{array}$} & An-Nahar: 9 & An-Nahar: $11.25 \%$ \\
\hline & Al Joumhouriya: 5 & Al Joumhouriya: $8.62 \%$ \\
\hline & Al Akhbar: 2 & Al Akhbar: $9.52 \%$ \\
\hline & The Daily Star: 7 & The Daily Star: $33.33 \%$ \\
\hline \multirow{3}{*}{$\begin{array}{l}\text { Ethics, and behavior (unkind, disagreeable, burden, dishonest, immoral, liar, } \\
\text { unjust, unethical, corrupt and others) }\end{array}$} & An-Nahar: 11 & An-Nahar: $13.75 \%$ \\
\hline & Al Joumhouriya : 7 & $\begin{array}{l}\text { Al Joumhouriya : } 12.06 \\
\%\end{array}$ \\
\hline & Al Akhbar: 1 & Al Akhbar: $4.76 \%$ \\
\hline
\end{tabular}

And news related to ethics, and behavior were frame as "unkind, disagreeable, burden, dishonest, immoral, liar, unjust, unethical, corrupt, and others." The results of Security Threat (table 2) illustrated by propositional and syntactical units revealed the following coverage. $27.5 \%$ out of An-Nahar articles, $25.85 \%$ out of AlJoumhouriyaarticles, $23.8 \%$ out of AlAkhbar articles, and $35.55 \%$ out of The Daily Star articles framed Syrian refugees as "thief, killer, rapist, trigger person, slayer, shoplifter, highway robber, and others, and related them to terrorism being framed as "terrorist, bomber, radical, and others.

Table 2: Content Categories Design of Security Threat Units, Frequency and Percentages

\begin{tabular}{|c|c|c|}
\hline \multicolumn{3}{|c|}{ Security Threat representing Syntactical units } \\
\hline Variables & \begin{tabular}{|c} 
Number of articles \\
that contain \\
prejudice \\
words/phrases
\end{tabular} & \begin{tabular}{|c|} 
Percentage of \\
Articles that contain \\
prejudice \\
words/phrases \\
\end{tabular} \\
\hline \multicolumn{3}{|l|}{ Any word or statement that represents Syrians as a threat to: } \\
\hline \multirow{4}{*}{$\begin{array}{l}\text { Security measurements (Thief, killer, rapist, trigger person, slayer, shoplifter, } \\
\text { highway robber, and others) }\end{array}$} & An-Nahar: 15 & An-Nahar: $18.75 \%$ \\
\hline & Al Joumhouriya : 9 & $\begin{array}{l}\text { Al Joumhouriya : } \\
15.51 \%\end{array}$ \\
\hline & Al Akhbar: 4 & Al Akhbar: $19.04 \%$ \\
\hline & The Daily Star: 13 & The Daily Star: $28.88 \%$ \\
\hline \multicolumn{3}{|l|}{ And relating them to } \\
\hline \multirow{4}{*}{ Terrorism (Terrorist, bomber, radical, and others) } & An-Nahar: 7 & An-Nahar: $8.75 \%$ \\
\hline & Al Joumhouriya: 6 & $\begin{array}{l}\text { Al Joumhouriya: } \\
10.34 \%\end{array}$ \\
\hline & Al Akhbar: 1 & Al Akhbar: $4.76 \%$ \\
\hline & The Daily Star: 3 & The Daily Star: $6.67 \%$ \\
\hline
\end{tabular}


The results of Economic Threat (table 3) illustrated by propositional and syntactical units revealed the following coverage. $18.75 \%$ out of An-Nahar articles, $24.13 \%$ out of Al Joumhouriya articles, $19.04 \%$ out of Al Akhbar articles, and $15.55 \%$ out of the Daily Star article framed refugees as "threat to the economy and the welfare of socio-political economic status, losing jobs for foreign labor, and more." Note: All these units are combined in "Thematic Unit," which means prejudice framing of Syrian Refugees in Lebanese media."

Table 3: Content Categories Design of Economic Threat Units, Frequency and Percentages

\begin{tabular}{|l|l|l|}
\hline \multicolumn{3}{|c|}{ Economic threat representing syntactical and propositional units } \\
\hline \multicolumn{1}{|c|}{ Variables } & $\begin{array}{c}\text { Number of articles } \\
\text { that contain } \\
\text { prejudice } \\
\text { words/phrases }\end{array}$ & $\begin{array}{c}\text { Percentage of } \\
\text { Articles that contain } \\
\text { prejudice } \\
\text { words/phrases }\end{array}$ \\
\hline $\begin{array}{l}\text { Any word or statement that represents Syrians as a threat to economy and the } \\
\text { welfare of socio-political economic status. }\end{array}$ & An-Nahar: 15 & $\begin{array}{l}\text { An-Nahar: 18.75\% } \\
\text { Al Joumhouriya: } \\
24.13 \%\end{array}$ \\
\hline
\end{tabular}

However, unlike the negative framing in covering the social, security, and economic affairs the analysis of Humanitarian cases (table 4) illustrated by propositional and syntactical units revealed a positive tone. AlAkhbar covered positive stories in $28.56 \%$ of the articles related to Syrian refugee crisis in Lebanon. Only $12.05 \%$ of Al Joumhouriya's articles, $11.25 \%$ of An-Nahar's articles, and $13.32 \%$ of The Daily Star articles covered humanitarian stories with a positive tone. This positive framing related to stories confirming the rights of Syrian refugees to have a "shelter, food, proper education, and safe environment."

Table 4: Content Categories Design of Humanitarian Units, Frequency and Percentages

\begin{tabular}{|c|c|c|}
\hline \multicolumn{3}{|c|}{ Humanitarian cases representing Propositional units } \\
\hline Variables & $\begin{array}{c}\text { Number of articles } \\
\text { that contain } \\
\text { prejudice } \\
\text { words/phrases }\end{array}$ & \begin{tabular}{|c|} 
Percentage of \\
Articles that contain \\
prejudice \\
words/phrases \\
\end{tabular} \\
\hline \multicolumn{3}{|c|}{$\begin{array}{l}\text { Stories that covered the Syrian refugee crisis from a humanitarian angle, such as } \\
\text { Stories of refugees that don't have: }\end{array}$} \\
\hline \multirow{4}{*}{ A shelter } & An-Nahar: 2 & An-Nahar: $2.5 \%$ \\
\hline & Al Joumhouriya: 2 & Al Joumhouriya: $3.44 \%$ \\
\hline & Al Akhbar: 1 & Al Akhbar: $4.76 \%$ \\
\hline & The Daily Star: 2 & The Daily Star: $4.44 \%$ \\
\hline \multirow{4}{*}{ Food } & An-Nahar: 0 & An-Nahar: $0 \%$ \\
\hline & Al Joumhouriya: 1 & Al Joumhouriya: $1.72 \%$ \\
\hline & Al Akhbar: 0 & Al Akhbar: $0 \%$ \\
\hline & The Daily Star: 2 & The Daily Star: $4.44 \%$ \\
\hline \multirow{4}{*}{ Proper Education } & An-Nahar: 2 & An-Nahar: $2.5 \%$ \\
\hline & Al Joumhouriya: 3 & Al Joumhouriya: $5.17 \%$ \\
\hline & Al Akhbar: 2 & Al Akhbar: $9.52 \%$ \\
\hline & The Daily Star: 1 & The Daily Star: $2.22 \%$ \\
\hline \multirow{4}{*}{ Safe Environment } & An-Nahar: 3 & An-Nahar: $3.75 \%$ \\
\hline & Al Joumhouriya: 0 & Al Joumhouriya: $0 \%$ \\
\hline & Al Akhbar: 2 & Al Akhbar: $9.52 \%$ \\
\hline & The Daily Star: 1 & The Daily Star: $2.22 \%$ \\
\hline \multirow{4}{*}{ And Others } & An-Nahar: 2 & An-Nahar: $2.5 \%$ \\
\hline & Al Joumhouriya: 1 & Al Joumhouriya: $1.72 \%$ \\
\hline & Al Akhbar: 1 & Al Akhbar: $4.76 \%$ \\
\hline & The Daily Star: O & The Daily Star: $0 \%$ \\
\hline
\end{tabular}




\section{Conclusion}

The media tendency of framing events related to Syrian refugees has contributed to placing them within a field of meaning. The impression of the media reality that this study provides cannot be separated from the complex situation in Lebanon, which has its specificity and which results in a media and political discourse revolving around fear. Journalists have selected subjectively the events they have covered about the Syrian refugees' crisis based on social norms, interest group pressure, political orientations and daily occurrences. They have framed stories affecting sociocultural, safety, economic, and humanitarian norms to influence the perception of the Lebanese people on how they shape their opinions towards the presence of this massive number of migrants in their country. The Lebanese media does not look void of the contradictions witnessed by the Lebanese society. And despite the caution in covering major events and abiding by objectivity in doing so, covering the events associated with asylum in the media indirectly strengthens the prejudice of a party already convinced that "the displaced persons and the refugees are the ones behind the problems and riots", or that most of the crimes are explained by the social factors. The news related to the "stranger", i.e. the Syrian in this case, are full of drifts that can feed the stereotypical definition. Successively, statistics were generated from studying the content of 204 articles covering socio-cultural, economic, humanitarian, and security news and retrieved from four mostly read newspapers in the country.

To answer the first and second research questions, the socio-cultural concepts framed by news media consisted ofnews related to society and contained terms as "Burden, beggar, thief, dirty, filthy, uneducated, dependent, and lower class." News related to culture and contained terms as "stupid, idiot, naïve, ignorant, masses, mindless, and absurd." News related to social norms and contained terms as "selfish, small, unmindful, mean, greedy, inattentive, unreasonable, and wanting." And news related to ethics, and behavior with words like "unkind, disagreeable, burden, dishonest, immoral, liar, unjust, unethical, and corrupt."

The Security Threat concepts framed by news media consisted of terms calling a Syrian refugee as "thief, killer, rapist, trigger person, slayer, shoplifter, highway robber, and others, and related him to terrorism being framed as "terrorist, bomber, radical, and others."

The Economic Threat framed by news media consisted of terms as "threat to the economy and the welfare of sociopolitical economic status, losing jobs for foreign labor, and more." As for humanitarian framing, positive tone was revealed assuring Syrian refugees the right to "shelter, food, proper education, and safe environment."To answer he third research question and relate it to the last research question, the results revealed that more than half of the coverage of The Dialy Star (53.33\%) are news concerning the effects of Syrian refugee crisis on the society, culture, social norms, and ethics and behaviors.

Similarly, nearly half the coverage of An-Nahar (42.5\%) tackled this particular propositional and syntactical unit, 37.91 $\%$ out of Al Joumhouriya coverage, and $23.8 \%$ out of AlAkhbar coverage. Nonetheless, the highest percentage of The Daily Star articles (35.55\%) covered stories related to security concerning Syrian refugees, followed by An-Nahar, Al Joumhouriya and AlAkhbar newspapers with $27.5 \%, 25.85 \%$, and $23.8 \%$ consecutively. Moreover, $18.75 \%$ out of AnNahar articles, $24.13 \%$ out of Al Joumhouriya articles, 19.04\% out of Al Akhbar articles, and 15.55\% out of the Daily Star article framed refugees as "threat to the economy and the welfare of socio-political economic status.

However, as for humanitarian framing, $\mathrm{Al}$

Akhbar covered positive stories in $28.56 \%$ of the articles, $12.05 \%$ of Al Joumhouriya's articles, $11.25 \%$ of AnNahar's articles, and $13.32 \%$ of The Daily Star articles. However, such positive stories have received the lowest as compared to the amount of coverage concerning socio-economic, security, and economic. From a framing theory perspective, it appears that out of 204 coverages observed, 78 have tackled the burdens of asylum, and what it entails in terms of social affairs and the threat of Syrian refugees on the Lebanese society, their behavior, ethics and norms. 58 of them addressed security issues related to Syrians and 40 of them related to economic burden. One can confirm that those subjects were intentionally framed by journalists to attract attention towards socio-cultural, security, and economic issues to motivate public opinions and make them interested in the situation they encounter which may make them in turn attempt at solving a sufficiently pressing socio-cultural problem away from their political leaders.

\section{Recommendations}

In the attempt to investigate the prejudice framing of socio-cultural, security, and economic stories in Lebanese media, this study revealed a significant amount of belittling terms against Syrian refugees with the intention of affecting the way Lebanese people perceived their threatening presence in their own country. However, despite the fact that there have been cases of heroic and inspiring journalism, which gave voices to the refugees in a sensitive and ethical manner, one should not deny the fact that journalism is under pressure from a weakening media economy. Political bias and opportunism that drive the news agenda is reflected by the dangers of hate-speech, stereotyping and social exclusion of 
refugees and migrants. What is unquestionable is that media everywhere play a vital role in bringing the world's attention to these events through the way they frame news. Reporters navigate internal news outlet policies, local political setting, access to refugees, knowledge of the intricacies of the subject, and time. Therefore, one can suggest to train journalists to be accurate, fair, and balanced in their reporting, i.e. to be ethical to the fullest possible extent. Train them on how to equip themselves with factual evidence and develop analytical skills to do in-depth reporting and accurate feature stories especially when they are dealing with subjects they are not familiar with. Train them to be more objective in reporting the positive aspects of any story as much as its negative aspects. Support journalists and media outlets from among the refugees to be the voices of their community especially as refugees in general have difficulties articulating their experience.

\section{References}

Abu-Fadil, M. (2015, December 17). Lebanon: Media Put Humanity in the Picture as Refugee Crisis Takes Hold. Retrieved April 23, 2017, from http://www.huffingtonpost.com/magda-abufadil/lebanon-media-puthumanit_b_8824826.html

Alsharabati, C. (2014). Survey on Perceptions of Syrian Refugees in Lebanon. Institut des Sciences Politiques. University Saint Joseph.

Althaus, Scott L., and Young Mie Kim. 2006. "Priming Effects in Complex Environments." Journal of Politics 68 (November): 960-76.

Australian Government Department of Immigration and Border Protection. (n.d.). Retrieved April 23, 2017, from http://www.border.gov.au/

Bargh, John A., Wendy J. Lombardi, and E. Tory Higgins. 1988. "Automaticity of Chronically Accessible Constructs in Person XSituation Effects on Perception." Journal of Personality and Social Psychology 55 (October): 599605.

Bateson, G. (1972). Steps to an ecology of mind: Collected essays in anthropology, psychology, evolution and epistemology. San Francisco, CA: Chandler.

Bless, Herbert, Klaus Fiedler, and Fritz Strack. 2004. Social Cognition. Hove, UK: Psychology Press.

Blinder, S. (2015). Imagined Immigration: The Impact of Different Meanings of Immigrants‘ in Public Opinion and Policy Debates in Britain. POLITICAL STUDIES; VOL 63

Brader, T., Valentino, N. A. and Suhay, E. (2008) 'What Triggers Public Opposition to Immigration? Anxiety, Group Cues, and Immigration Threat', American Journal of Political Science, 52 (4), 959-978.

Brewer, Paul R. 2001. "Value Words and Lizard Brains." Political Psychology 22 (March): 45-64.

Brewer, P.R., and Gross, K. (2005) "Values, framing, and citizens' thoughts about policy issues: Effects on

content and quantity," Political Psychology, 26(6): 929-948.

Bryant, J., \& Oliver, M. B. (Eds). (2009). Media effects: Advances in theory and research (3rd ed.). New York: Routledge.

Cacciatore, MA, Scheufele, DA, Iyengar, S (2016) The end of framing as we know it ... and the future of media effects. Mass Communication and Society 19(1): 7-23. Google Scholar, ISI

Cappella, Joseph N., and Kathleen Hall Jamieson. 1997. Spiral of Cynicism. New York: Oxford University Press.

Castles, Stephen, Hein de Haas, and Mark. J. Miller. 2014. The Age of Migration: International Population Movements in the Modern World. 5th revised edition. Houndmills, Basingstoke, Hampshire and London: MacMillan Pres ltd, chapter 1, chapter 2, pages 25-28.

Ceobanu, A. M. and Escandell, X. (2010) 'Comparative Analyses of Public Attitudes toward Immigrants and Immigration using Multinational Survey Data: A Review of Theories and Research', Annual Review of Sociology, 36, 309-328.

Chong, D. and Druckman, J.N. (2007a) "Framing public opinion in competitive democracies," American Political Science Review 101: 637-655.

Chong, D. and Druckman, J.N. (2007b) "A theory of framing and opinion formation in competitive elite environments," Journal of Communication 57: 99-118.

Citrin, J. and Sides, J. (2008) 'Immigration and the Imagined Community in Europe and the United

States', Political Studies, 56 (1), 33-56.

Crossman, A. (n.d.). Understanding Purposive Sampling. Retrieved April 23, 2017, from https://www.thoughtco.com/purposive-sampling-3026727

Druckman, J. N. (2001). On the limits of framing effects: Who can frame? Journal of Politics, 63, 1041-1066.

Eagly Alice H., and Shelly Chaiken. 1993. The Psychology of Attitudes. Fort Worth: Harcourt Brace. 
Facchini, G., Mayda, A. M. and Puglisi, R. (2013) 'Individual Attitudes towards Immigration: Economic vs. Non-economic Determinants', in G. P. Freeman, R. Hansen and D. Leal (eds), Immigration and Public Opinion in Liberal Democracies. New York: Routledge, pp. 129-157.

Fazio, Russell H. 1995. "Attitudes as Object-Evaluation Associations." In Attitude Strength: Antecedents and Consequences, eds. $\quad$ Richard E. Petty, and Jon A. Krosnick. Hillsdale, NJ: Erlbaum, 247-282.

Fetzer, J. S. (2000) Public Attitudes toward Immigration in the United States, France, and Germany. Cambridge: Cambridge University Press.

Figenschou, T. U., Beyer, A. and Thorbjørnsrud, K. The Moral Police. Agenda-setting and Framing Effects of a New(s) Concept of Immigration; Nordicom Review 36 (2015).

France Strategie (2016) Les conséquences économiques d'un abandon des accords de Schengen, http://www.strategie.gouv.fr/publications/consequenceseconomiques-dun-abandon-accords-deschengen?xtor=xtor\%3DEREC-10-\%5B20160204-ALERTE038\%5D.

Frey, L. R., Anderson, S., \& Friedman, P. G. (1998). The status of instruction in qualitative communication research methods. Communication Education, 47(3), 246-260.

Goffman, E. (1974). Frame Analysis: An Essay on the Organization of Experience. . New York, NY et al.: Harper \& Row.

Hainmueller, J. and Hiscox, M. J. (2010) 'Attitudes toward Highly Skilled and Low-Skilled Immigration: Evidence from a Survey Experiment', American Political Science Review, 104 (1), 61-84.

Hejase, A.J., \& Hejase, H.J. (2013). Research Methods: A Practical Approach for Business

Students, (2nd edition). Philadelphia, PA: Massadir Inc.

Holsti, O. R. (1969). Content analysis for the Social Sciences and Humanities.

Hugo, G, Ahazram, C \& Appave, G 2011, "Communiating effectively about migration, in G Hugo, C Ahazram, C \& G Appave (eds), World Migration Report 2011, International Organization for Migration, Geneva.

Human migration. (n.d.). Retrieved April 23, 2017, from http://www.newworldencyclo pedia.org/entr y/Human_migration

IOM History. (2016, July 07). Retrieved April 23, 2017, from https://www.iom.int/iom-history

IOM -- Essentials of Migration Management: Volume One, (2014) (n.d.). Retrieved April 23, 2017, from http://www.rcmvs.org/documentos/IOM_EMM/v1/volume1.html

Ipsos MORI (2010) 'Where Does the Public Stand on Immigration?' Available from: http://www. ipsosmori.com/ _emails/sri/latestthinking/aug2010/content/7_where-do-the-public-stand-on-immigration.pdf[Accessed 16 February 2011].

Irving, L. M., (1990). Mirror images: Effects of the standard of beauty on the self- and body-esteem of women exhibiting varying levels of bulimic symptoms. Journal of Clinical and Applied Psychology, 9(2), 230-242.

Krippendorff, K. (2004). Content analysis: An introduction to its methodology. Sage.

Lippmann, W. (1997 [1922]) Public Opinion. New York: Free Press.

Maharat (n.d.). Retrieved April 23, 2017, from http://www.maharatfoundation. org/PublicationDe tails.aspx?id=124 $3 \&$ language $=$ ar

Mass Communication Theory on WordPress.com. (n.d.). Retrieved April 23, 2017, from https://masscommtheory.com/

McAuliffe, M. (2016). Media and migration: Comparative analysis of print and online media reporting on migrants and migration in selected origin and destination countries

Nabi, R. L. (2003). "Feeling" resistance: Exploring the role of emotionally evocative visuals in inducing inoculation. Media Psychology, 5, 199-223.

Nelson, Thomas E., Zoe M. Oxley, and Rosalee A. Clawson. 1997. "Toward a Psychology of Framing Effects." Political Behavior 19 (September): 221-46.

O’Rourke, K., R. Sinnott, 2006, “The Determinants of Individual Attitudes Towards Immigration,” European Journal of Political Economy, $22: 838-861$.

Price,Vincent, and David Tewksbury. 1997. "NewsValues and Public Opinion." In Progress in Communication Sciences. Vol. 13, eds. George A. Barnett, and Franklin J. Boster. Greenwich, CT: Ablex Publishing Corporation.

Pylyshyn Z W. What the mind's eye tells the mind's brain: a critique of mental imagery. Psychol. Bull. 80:1-24, 1973. [Univ. Western Ontario, London, Ontario, Canada]

Quillian, L. (1995) 'Prejudice as a Response to Perceived Group Threat: Population Composition and Anti-immigrant and Racial Prejudice in Europe', American Sociological Review, 60 (4), 586-611.

Saqer Mustafa Sqour, M., Rjoub. A., andTarrad, M. Development and Trends of Urban Growth in Mafraq City, Jordan. Architecture Research 2016, 6(5): 116-122

DOI: $10.5923 / \mathrm{j}$.arch.20160605.02 
Semyonov, M., Raijman, R. and Gorodzeisky, A. (2008) 'Foreigners' Impact on European Societies', International Journal of Comparative Sociology, 49 (1), 5-29.

Stapel, Diederik, Willem Koomen, and Marcel Zeelenberg. 1998. "The Impact of Accuracy Motivation on Interpretation, Comparison, and Correction Processes." Journal of Personality and SocialPsychology 74 (April): 878-93.

Threadgold, T. (2009) The Media and Migration in the United Kingdom, 1999 to 2009.Washington, DC: Migration Policy Institute

UNHCR, (2015). Impact of Refugees on Human Issues and Behavior: Advantages and disadvantages

United Nations Department of Economic and Social Affairs, (2013). Refugees and Economy: Hints and Measures

Zaller, J. (1992) The Nature and Origins of Mass Opinion. Cambridge: Cambridge University Press. 